\title{
PENINGKATAN KEMAMPUAN KOMUNIKASI MATEMATIS MELALUI MODEL PEMBELAJARAN KOOPERATIF TIPE THINK TALK WRITE (TTW) DENGAN MEDIA LKPD PADA MATERI RELASI DAN FUNGSI SISWA KELAS VIII-B MTS AL-MA'ARIF BOCEK KARANGPLOSO TAHUN PELAJARAN 2017/2018
}

\author{
Rizka Rufaidah ${ }^{1}$ \\ ${ }^{I}$ MTS Al-Ma'arif Bocek Karangploso

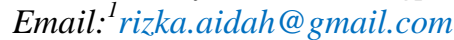

\begin{abstract}
Abstrak
Penelitian tindakan kelas ini dilatar belakangi oleh kurangnya kemampuan peserta didik dalam hal komunikasi matematis. Penelitian ini bertujuan untuk mendeskripsikan peningkatkan kemampuan komunikasi matematis melalui model pembelajaran kooperatif tipe Think Talk Write menggunakan media LKPD pada materi relasi dan fungsi peserta didik kelas VIII-B MTs Al-Ma'arif Bocek Karangploso tahun pelajaran 2017/2018 yang dilaksanakan pada 27 April-7 Mei 2018. Jenis penelitian yang digunakan adalah penelitian tindakan kelas dengan 2 siklus, yang terdiri dari 2 pertemuan pada setiap siklus. Adapun tahapan setiap siklus meliputi perencanaan, pelaksanaan, pengamatan dan refleksi. Teknik dan alat pengumpulan data pada penelitian ini menggunakan teknik analisis deskriptif terhadap data berupa dokumen hasil pekerjaan siswa, daftar nilai dan hasil observasi. Hasil penelitian menunjukan bahwa dengan model pembelajaran kooperatif tipe Think Talk Write terjadi suasana pembelajaran yang kondusif sehingga kemampuan komunikasi matematis peserta didik meningkat, dari hasil penelitian, diketahui bahwa siklus I ke siklus II terdapat peningkatan, pada siklus I presentase ketuntasan belajar siswa mencapai 55,56\% sedangkan pada siklus II terjadi peningkatan dengan presentase keberhasilan mencapai $77,8 \%$. Hasil observasi aktivitas guru pada siklus I mencapai $83,05 \%$ dan mengalami peningkatan pada siklus II menjadi $86,05 \%$. Sedangkan hasi observasi aktivitas peserta didik pada siklus I adalah $77,98 \%$ mengalami peningkatan pada siklus II menjadi $83,08 \%$. Serta hasil wawancara pada siklus I yakni 3 peserta didik (50\%) menjadi 4 peserta didik $(66,67 \%)$ merasa senang dengan penerapan model pembelajaran kooperatif tipe TTW menggunakan media LKPD. Sehingga disimpulkan bahwa model pembelajaran kooperatif tipe Think Talk Write dapat meningkatkan kemampuan komunikasi matematis.
\end{abstract}

Kata-kata kunci: Think Talk Write, relasi dan fungsi, media LKPD, dan kemampuan komunikasi matematis

\section{PENDAHULUAN}

Pendidikan bertujuan untuk berkembangnya potensi peserta didik agar menjadi manusia yang beriman dan bertakwa kepada Tuhan Yang Maha Esa, berakhlak mulia, sehat, berilmu, cakap, kreatif, mandiri, dan menjadi warga negara yang demokratis serta bertanggung jawab. Tujuan pendidikan tersebut dapat dicapai melalui proses pendidikan. Dibutuhkan proses pendidikan yang baik untuk mencapai tujuan pendidikan yang maksimal. Salah satunya terjadi dalam proses pembelajaran.

Dalam proses pembelajaran khususnya pada mata pelajaran matematika, peserta didik lebih difokuskan pada kemampuan menghitung, tetapi kurang memperhatikan kemampuan peserta didik dalam mengungkapkan hasil pemikiran mereka baik secara lisan maupun dalam bentuk tulisan. Menurut Lestari dan Yudhanegara (2017:83), kemampuan menyampaikan gagasan/ide matematis, baik secara lisan maupun tulisan adalah kemampuan komunikasi matematis. 
Menurut Baroody (dalam Hendriana 2017:59), komunikasi matematis merupakan modal dalam menyelesaikan, mengeksplorasi, dan menginvestigasi matematik dan merupakan wadah dalam beraktivitas sosial dengan temannya, berbagi pikiran dan penemuan, curah pendapat, menilai dan mempertajam ide untuk meyakinkan orang lain. Oleh karena itu penting bagi peserta didik memiliki kemampuan komunikasi matematis yang baik.

Meskipun kemampuan komunikasi matematis itu penting namun pada kenyataannya dalam proses pembelajaran peserta didik tidak berani mengemukakan pendapatnya merasa khawatir jika keliru. Ketika peserta didik diberi pertanyaan terkait materi yang disajikan dalam bentuk gambar ataupun diagram, peserta didik tidak dapat menterjemahkan informasi dalam gambar atau diagram tersebut. Dengan demikian dibutuhkan model pembelajaran yang tepat untuk meningkatkan kemampuan komunikasi matematis peserta didik.

Berdasarkan hasil wawancara terhadap guru MTs Al-Ma'arif Bocek Karangploso, diperoleh informasi bahwa proses pembelajaran matematika menggunakan metode konvensional dengan sistem ceramah, namun terkadang diselingi dengan metode diskusi. Meskipun peserta didik diskusi namun ketika diajukan pertanyaaan peserta didik kesulitan dalam menjelaskan apa yang mereka peroleh. Kemampuan menyampaikan gagasan/ide matematis, baik secara lisan maupun tulisan adalah kemampuan komunikasi matematis.

Salah satu upaya untuk meningkatkan kemampuan komunikasi adalah melalui model pembelajaran kooperatif tipe think talk write (TTW) menggunakan media LKPD. Model pembelajaran kooperatif tipe TTW merupakan model pembelajaran dimana peserta didik dituntut untuk menyampaikan informasi hasil diskusi kepada kelompok lain sehingga dapat memberikan dampak positif bagi peningkatan kemampuan komunikasi matematis peserta didik.

Model pembelajaran TTW mendorong peserta didik untuk mengkonstruksi pengetahuan yang memuat pemahaman dan komunikasi matematika dalam bentuk tulisan dari media yang diberikan. Maka dari itu adanya media dianggap perlu sebagai penunjang dalam kegiatan pembelajaran. Dalam hal ini peneliti akan menggunakan media LKPD (lembar kerja peserta didik). LKPD termasuk media pembelajaran cetak yang dapat digunakan untuk menciptakan proses pembelajaran yang efektif dan efisien, (Fitriyati dkk (dalam Nur 2017:157)).

Berdasarkan uraian di atas, maka peneliti akan melakukan penelitian dengan judul "Peningkatan Komunikasi Matematis Melalui Model Pembelajaran Kooperatif Tipe Think Talk Write (TTW) Menggunakan Media LKPD Pada Materi Relasi dan Fungsi Peserta didik Kelas VIIIB MTs Al Maarif Bocek Karangploso Tahun Pelajaran 2017/2018”.

Berdasarkan uraian di atas, rumusan masalah dalam penelitian ini adalah bagaimana peningkatkan kemampuan komunikasi matematis melalui model pembelajaran kooperatif tipe Think Talk Write menggunakan media LKPD pada materi relasi dan fungsi peserta didik kelas VIII-B MTs Al-Ma'arif Bocek Karangploso tahun pelajaran 2017/2018?

Sesuai dengan rumusan masalah di atas, tujuan penelitian ini adalah untuk mendeskripsikan peningkatkan kemampuan komunikasi matematis melalui model pembelajaran kooperatif tipe Think Talk Write menggunakan media LKPD pada materi relasi dan fungsi peserta didik kelas VIII-B MTs Al-Ma'arif Bocek Karangploso tahun pelajaran 2017/2018.

Menurut Lestari dan Yudhanegara (2017:83), kemampuan komunikasi matematis adalah kemampuan menyampaikan gagasan/ide matematis, baik secara lisan maupun tulisan serta kemampuan memahami dan menerima gagasan/ide matematis orang lain secara cermat, analitis, kritis, dan evaluatif untuk mempertajam pemahaman. Dapat dikatakan bahwa kemampuan komunikasi matematis adalah kemampuan menjelaskan hasil pemahaman individu melalui simbol maupun kalimat. Dalam penelitian ini, kemampuan komunikasi matematis yang akan diukur terdapat 3 indikator: (1) Menyatakan peristiwa sehari-hari ke dalam bentuk model matematika (diagram panah, koordinat cartesius, dan himpunan pasangan berurut); (2) Menjelaskan model matematika (diagram panah atau diagram kartesius) ke dalam bahasa biasa; dan (3) Menjelaskan definisi relasi dan fungsi. 
Menurut Huda, (2016:218) Model Pembelajaran TTW mendorong peserta didik untuk berpikir, berbicara dan kemudian menuliskan suatu topik tertentu. Model pembelajaran ini digunakan untuk mengembangkan tulisan dengan lancar dan melatih bahasa sebelum dituliskan. Model Pembelajaran TTW membantu peserta didik dalam mengumpulkan dan mengembangkan ide melalui percakapan terstruktur. Dengan sintak (1) Peserta didik membaca teks dan membuat catatan dari hasil bacaan secara individual (think), (2) Peserta didik berinteraksi dan berkolaborasi dengan teman satu grup untuk membahas isi catatan(talk), (3) Peserta didik mengkonstruksi sendiri pengetahuan yang memuat pemahaman dan komunikasi matematika dalam bentuk tulisan (write), (4) Peserta didik membuat refleksi dan kesimpulan atas materi yang dipelajari.

Fitriyati dkk (dalam Nur 2017:157) menyatakan bahwa LKPD termasuk media pembelajaran cetak yang dapat digunakan untuk menciptakan proses pembelajaran yang efektif dan efisien.. Sehingga LKPD dapat dikatakan sebagai media cetak yang berisi materi dan panduan pengerjaan soal untuk menciptakan proses pembelajaran yang efektif.

\section{METODE}

Pendekatan yang digunakan dalam penelitian ini adalah kualitatif, sedangkan jenis penelitiannya adalah penelitian tindakan kelas. Penelitian ini dilaksanakan di MTs Al-Ma'arif yang terletak di J1 Raya Bocek No3. Karangploso. Adapun subjek penelitiannya adalah peserta didik kelas VIII-B yang berjumlah 18 peserta didik.

Adapun teknik pengumpulan data dalam penelitian ini dilakukan dengan: (1) tes, digunakan untuk memperoleh data kemampuan komunikasi matematis, (2) wawancara, digunakan untuk untuk mengetahui tanggapan peserta didik mengenai model pembelajaran Think Talk Write (TTW) dengan media LKPD, (3) observasi, digunakan untuk mengamati aktivitas guru dan peserta didik selama proses pembelajaran berlangsung, dan (4) catatan lapangan, digunakan untuk melengkapai data yang tidak tercantum dalam lembar observasi.

Instrumen yang digunakan dalam penelitian ini adalah sebagai berikut: (1) soal tes, menggunakan soal tes tulis dalam bentuk uraian yang disesuaikan dengan indikator kemampuan komunikasi matematis, (2) pedoman wawancara, (3) lembar observasi, terdiri dari lembar observasi aktivitas guru dan lembar observasi aktivitas peserta didik. Observasi dilaksanakan selama proses pembelajaran berlangsung, dan (4) pedoman catatan lapangan, diisi oleh dua pengamat yaitu guru mata pelajaran matematika kelas VIII-B dan teman sejawat.

Analisis data dilakukan setelah pemberian tindakan. Analisis data dalam penelitian ini terdiri dari: (1) analisis data kualitatif, yaitu: reduksi data (data reduction), penyajian data (data display), dan penarikan kesimpulan atau verifikasi (conclusion drawing/verification), dan (2) analisis data kuantitatif, dianalisis dengan menggunakan rumus persentase ketuntasan belajar dan rata-rata kelas.

\section{HASIL}

Tabel 1. Hasil Observasi Aktivitas Guru Siklus I

\begin{tabular}{|c|c|c|c|c|}
\hline \multirow[b]{2}{*}{ No } & \multirow[b]{2}{*}{ Aktivitas Guru } & \multicolumn{3}{|c|}{ Skor } \\
\hline & & Maksimal & Pengamat I & $\begin{array}{l}\text { Pengamat } \\
\text { II }\end{array}$ \\
\hline 1. & Awal (Pendahuluan) & 16 & 13 & 14 \\
\hline 2. & Inti & 36 & 30 & 28 \\
\hline 3. & Akhir (Penutup) & 16 & 15 & 13 \\
\hline & Total Skor & 68 & 58 & 55 \\
\hline & Persentase & $100 \%$ & $85,3 \%$ & $80,8 \%$ \\
\hline & Taraf Keberhasilan & Sangat Baik & Sangat baik & Sangat baik \\
\hline
\end{tabular}

Tabel 2. Hasil Obsevasi Aktivitas Peserta Didik Siklus I

\begin{tabular}{|l|l|l|l|l|}
\hline \multirow{2}{*}{ No } & \multirow{2}{*}{ Aktivitas Peserta didik } & \multicolumn{3}{|c|}{ Skor } \\
\cline { 3 - 5 } & & Maksimal & Pengamat & Pengamat \\
\hline
\end{tabular}




\begin{tabular}{|l|l|c|c|c|}
\hline & & & I & II \\
\hline 1. & Awal (Pendahuluan) & 16 & 14 & 14 \\
\hline 2. & Inti & 36 & 27 & 27 \\
\hline 3. & Akhir (Penutup) & 16 & 13 & 11 \\
\hline \multicolumn{2}{r|}{ Total Skor } & 68 & 54 & 52 \\
\hline \multicolumn{2}{r|}{ Persentase } & $100 \%$ & $79,48 \%$ & $76,47 \%$ \\
\hline Taraf Keberhasilan & Sangat Baik & Baik & Baik \\
\hline
\end{tabular}

\section{Hasil Catatan Lapangan siklus I}

Dari hasil catatan lapangan yang dilakukan oleh pengamat I dan II dapat disimpulkan:

1. Peserta didik terlihat senang dengan model pembelajaran yang digunakan

2. Peserta didik terlihat bersemangat mengerjakan permasalahan yang diberikan, namun ada beberapa yang masih bingung dan mengajukan pertanyaan.

3. Perhatian guru terhadap peserta didik kurang menyeluruh

Tabel 3. Hasil Tes Akhir siklus I

\begin{tabular}{|c|l|c|}
\hline No & \multicolumn{1}{|c|}{ Hasil Tes Akhir Siklus I } & Jumlah \\
\hline 1. & Nilai tertinggi & 85 \\
\hline 2. & Nilai terendah & 30 \\
\hline 3. & Nilai rata-rata kelas & 58,61 \\
\hline 4. & Jumlah peserta didik yang tuntas & 10 \\
\hline 5. & Jumlah peserta didik yang tidak tuntas & 8 \\
\hline 6. & Persentase keberhasilan & $55,56 \%$ \\
\hline
\end{tabular}

Tabel 4. Kriteria Keberhasilan Minimal

\begin{tabular}{|l|l|c|c|c|}
\hline No & \multicolumn{1}{|c|}{ Aspek yang Dinilai } & $\begin{array}{c}\text { Kriteria Keberhasilan } \\
\text { Minimal }\end{array}$ & $\begin{array}{c}\text { Hasil } \\
\text { penelitian }\end{array}$ & Keterangan \\
\hline 1. & Ketuntasan hasil tes akhir siklus I & $\geq 70 \%$ & $55,56 \%$ & Belum terpenuhi \\
\hline 2. & Aktivitas Peserta didik & $\geq 80 \%$ & $77,98 \%$ & Belum terpenuhi \\
\hline 3. & Aktivitas Guru & $\geq 80 \%$ & $83,05 \%$ & Terpenuhi \\
\hline 4. & $\begin{array}{l}\text { Respon peserta didik senang terhadap } \\
\text { model pembelajaran yang digunakan }\end{array}$ & $>50 \%$ & $50 \%$ & Belum terpenuhi \\
\hline
\end{tabular}

Berdasarkan tabel di atas dapat diketahui bahwa dari empat kriteria keberhasilan yang telah ditetapkan, hanya satu yang dinyatakan memenuhi kriteria tersebut.

Tabel 5. Hasil Observasi Aktivitas Guru Siklus II

\begin{tabular}{|l|c|c|c|c|}
\hline \multirow{2}{*}{ No } & \multirow{2}{*}{ Aktivitas Guru } & \multicolumn{3}{|c|}{ Skor } \\
\cline { 3 - 5 } & & Maksimal & Pengamat I & Pengamat II \\
\hline 1. & Awal (Pendahuluan) & 16 & 14 & 14 \\
\hline 2. & Inti & 36 & 30 & 31 \\
\hline 3. & Akhir (Penutup) & 16 & 15 & 13 \\
\hline \multicolumn{2}{r|}{ Total Skor } & 68 & 59 & 58 \\
\hline \multicolumn{2}{r|}{ Persentase } & $100 \%$ & $86,8 \%$ & $85,29 \%$ \\
\hline \multicolumn{2}{|c|}{ Taraf Keberhasilan } & Sangat Baik & Sangat baik & Sangat baik \\
\hline
\end{tabular}

Tabel 6. Hasil Obsevasi Kegiatan Peserta Didik Siklus II

\begin{tabular}{|l|c|c|c|c|}
\hline \multirow{2}{*}{ No } & \multirow{2}{*}{ Aktivitas Peserta didik } & \multicolumn{3}{|c|}{ Skor } \\
\cline { 3 - 5 } & & Maksimal & Pengamat I & Pengamat II \\
\hline 1. & Awal (Pendahuluan) & 16 & 14 & 15 \\
\hline
\end{tabular}




\begin{tabular}{|l|l|c|c|c|}
\hline 2. & Inti & 36 & 28 & 29 \\
\hline $3 . \quad$ Akhir (Penutup) & 16 & 14 & 13 \\
\hline \multicolumn{2}{r|}{ Total Skor } & 68 & 56 & 57 \\
\hline \multicolumn{2}{r|}{ Persentase } & $100 \%$ & $82,35 \%$ & $83,82 \%$ \\
\hline \multicolumn{2}{r|}{ Taraf Keberhasilan } & Sangat Baik & Sangat Baik & Sangat Baik \\
\hline
\end{tabular}

\section{Hasil Catatan Lapangan siklus II}

Dari hasil catatan lapangan yang dilakukan oleh pengamat I dan II dapat disimpulkan:

1. Peserta didik senang dengan model pembelajaran yang digunakan.

2. Peserta didik antusias mengerjakan permasalahan yang diberikan, hal ini dapat dilihat dari usaha peserta didik dalam mengerjakan permasalahan yang diberikan.

3. Peserta didik mengikuti intruksi guru dengan baik.

4. Keadaan kelas tertib dan kondusif pada saat proses pembelajaran berlangsung.

Tabel 7. Hasil Tes Akhir Siklus II

\begin{tabular}{|c|l|c|}
\hline No & \multicolumn{1}{|c|}{ Hasil Tes Akhir Siklus II } & Jumlah \\
\hline 1. & Nilai tertinggi & 95 \\
\hline 2. & Nilai terendah & 20 \\
\hline 3. & Nilai rata-rata kelas & 73,3 \\
\hline 4. & Jumlah peserta didik yang tuntas & 14 \\
\hline 5. & Jumlah peserta didik yang tidak tuntas & 4 \\
\hline 6. & Persentase keberhasilan & $77,8 \%$ \\
\hline
\end{tabular}

Tabel 8. Kriteria Keberhasilan Minimal

\begin{tabular}{|l|l|c|c|c|}
\hline No & \multicolumn{1}{|c|}{ Aspek yang Dinilai } & $\begin{array}{c}\text { Kriteria } \\
\text { Keberhasilan } \\
\text { Minimal }\end{array}$ & $\begin{array}{c}\text { Hasil } \\
\text { penelitian }\end{array}$ & Keterangan \\
\hline 1. & Ketuntasan hasil tes akhir siklus II & $\geq 70 \%$ & $77,8 \%$ & Terpenuhi \\
\hline 2. & Aktivitas Peserta didik & $\geq 80 \%$ & $83,08 \%$ & Terpenuhi \\
\hline 3. & Aktivitas Guru & $\geq 80 \%$ & $86,05 \%$ & Terpenuhi \\
\hline 4. & $\begin{array}{l}\text { Respon peserta didik senang terhadap } \\
\text { model pembelajaran yang digunakan }\end{array}$ & $>50 \%$ & $66,67 \%$ & Terpenuhi \\
\hline
\end{tabular}

Berdasarkan tabel di atas dapat diketahui bahwa keempat aspek yang dinilai dalam penelitian ini seluruhnya telah mencapai kriteria keberhasilan minimal yang ditetapkan, yaitu keterlaksanaan metode pembelajaran kooperatif tipe Think Talk Write dengan media LKPD aktivitas guru dengan persentase $86,05 \%$, aktivitas peserta didik dengan persentase $83,08 \%$, hasil tes akhir siklus mencapai $77,8 \%$, dan respon peserta didik dengan persentase $66,67 \%$. Hasil tersebut mengalami peningkatan dibandingkan hasil yang diperoleh pada siklus sebelumnya. Hal ini berarti bahwa kemampuan komunikasi matematis peserta didik telah meningkat.sehingga peneliti tidak perlu memberikan tindakan pada siklus berukutnya.

\section{PEMBAHASAN}

Pada pelaksanaan tindakan siklus I dan siklus II, guru memberikan materi tentang perbandingan dengan menggunakan model pembelajaran kooperatif tipe Think Talk Write dengan media LKPD. langkah-langkah pembelajaran: (1) Penyampaikan tujuan pembelajaran yang ingin dicapai, (2) Menjelaskan model pembelajaran yang akan digunakan, (3) Membagi peserta didik dalam beberapa kelompok, (4) Memberikan penjelasan secara umum mengenai materi yang akan dipelajari, (5) Peserta didik membaca, memahami, serta mengidentifikasi masalah yang diberikan dan membuat catatan sendiri tentang permasalahan tersebut (think), (6) Peserta didik berdiskusi 
dengan teman satu kelompok tentang catatan yang telah mereka buat dan menyelesaikan permasalahan yang diberikan (talk), (7) Peserta didik menyusun jawaban dari permasalahan yang telah didiskusikan dalam kelompok ke dalam bentuk tulisan (write), (8) Kelompok terpilih harus mempresentasikan hasil diskusi mereka dan kelompok lain menanggapi hasil presentasi (9) Merangkum isi pembelajaran dan (10) Penutup.

Berdasarkan hasil analisis data diperoleh informasi bahwa terjadi peningkatan kemampuan komunikasi matematis. Peningkatan tersebut antara lain dapat dilihat dari hasil tes akhir siklus I dan II. Di mana setiap butir soal yang digunakan pada setiap tes akhir siklus telah disesuaikan dengan indikator komunikasi matematis. Untuk lebih jelasnya, hasil penelitian telah diuraikan dan didapatkan data tentang komunikasi matematis peserta didik kelas VIII-B MTs Al-Ma'arif Bocek pada siklus I dan siklus II.

1) Pada tes akhir siklus I dari 18 siswa yang mengikuti tes akhir siklus diperoleh data banyak siswa yang tuntas adalah 10 siswa dan banyak siswa yang tidak tuntas belajar sebanyak 8 siswa dengan persentase $55,56 \%$.

2) Pada tas akhir siklus II dari 18 siswa yang mengikuti tes akhir siklus diperoleh data banyak siswa yang tuntas adalah 14 siswa dan banyak siswa yang tidak tuntas belajar sebanyak 4 siswa dengan persentase $77,8 \%$.

Berdasarkan hasil tes kemampuan komunikasi matematis pada materi relasi dan fungsi dalam penelitian ini, dapat diketahui bahwa komunikasi matematis peserta didik mengalami peningkatan sebesar 22,24\%. Persentase ketuntasan belajar tes hasil belajar matematika peserta didik pada materi relasi dan fungsi dapat dilihat pada tabel di bawah ini.

Tabel 9. Presentase Ketuntasan Siklus

\begin{tabular}{|l|l|}
\hline Tes & Prosentase Ketuntasan \\
\hline Tes akhir siklus I & $55,56 \%$ \\
\hline Tes akhir siklus II & $77,8 \%$ \\
\hline
\end{tabular}

Dari uraian di atas, dapat disimpulkan bahwa model pembelajaran kooperatif tipe Think Talk Write merupakan salah satu alternatif model pembelajaran matematika yang bertujuan untuk meningkatkan kemampuan komunikasi matematis khususnya pada materi relasi dan fungsi. Sehingga dapat disimpulkan bahwa pada penelitian ini, penerapan model pembelajaran kooperatif tipe Think Talk Write dengan media LKPD dapat meningkatkan komunikasi matematis peserta didik kelas VIII-B MTs Al-Ma'arif Bocek pada materi relasi dan fungsi tahun pelajaran 2017/2018.

\section{SIMPULAN DAN SARAN}

Berdasarkan hasil penelitian dan pembahasan, secara umum dapat disimpulkan bahwa model pembelajaran kooperatif tipe Think Talk Write (TTW) dengan media LKPD dapat meningkatkan komunikasi matematis pada peserta didik kelas VIII B MTs Al-Ma'arif Bocek Karangploso tahun pelajaran 2017/2018 dengan langkah-langkah pembelajaran (1) Kegiatan awal guru menyampaikan tujuan pembelajaran yang ingin dicapai kemudian menjelaskan model pembelajaran yang akan digunakan dan membagi peserta didik dalam beberapa kelompok. (2) Kegiatan inti guru memberikan penjelasan secara umum mengenai materi yang akan dipelajari, kemudian meminta peserta didik untuk mengidentifikasi masalah yang diberikan dan membuat catatan sendiri tentang permasalahan tersebut (think), kegiatan selanjutnya guru meminta peserta didik untuk berinteraksi, berkolaborasi, dan berdiskusi dengan teman satu kelompok tentang catatan yang telah mereka buat dan menyelesaikan permasalahan yang diberikan (talk), dilanjutkan dengan meminta peserta didik menyusun jawaban dari permasalahan yang telah didiskusikan dalam kelompok ke dalam bentuk tulisan (write), serta memilih secara acak kelompok yang harus mempresentasikan hasil diskusi mereka. Kemudian meminta kelompok lain menanggapi hasil presentasi kelompok terpilih. (3) Kegiatan akhir, guru memandu peserta didik merangkum isi 
pembelajaran dan menginformasikan garis besar kegiatan pada pertemuan berikutnya serta memberikan PR, kemudian berdo'a bersama dan mengucapkan salam penutup.

Berdasarkan paparan data dan pembahasan, peneliti menyarankan kepada berbagai pihak, sebagai berikut. (1) Bagi Sekolah, hasil penelitian ini dapat dijadikan sebagai acuan dalam mengambil kebijakan terkait dengan peningkatan proses pembelajaran di sekolah. (2) Bagi Guru Bidang Studi Matematika, hasil penelitian ini dapat digunakan sebagai salah satu alternatif model pembelajaran yang dapat digunakan untuk meningkatkan komunikasi matematis dan agar dapat dikembangkan secara inovatif. (3) Bagi Peneliti Lain, untuk selanjutnya dapat menerapkan model pembelajaran kooperatif tipe Think Talk Write (TTW) dengan media lain atau pada pokok bahasan lain dan disarankan untuk menjadikan hasil penelitian ini sebagai bahan rujukan dalam penelitian.

\section{DAFTAR RUJUKAN}

Huda, M. (2016). Model-model Pengajaran dan Pembelajaran (Isu-isu Metodis dan Paradigmatis). Yogyakarta: Pustaka Pelajar.

Hendriana, H., Rohaeti, E. E., Sumarmo, U. (2017). Hard Skills dan Soft Skills Matematik Siswa. Bandung: PT Refika Aditama.

Lestari, K. E., \& Yudhanegara, M. R. (2017). Penelitian Pendidikan Matematika. Bandung: PT Refika Aditama

Nur, M. (2017). Pengaruh Model Pemecahan Masalah Polya Berbantuan LKPD Terhadap Kemampuan Menganalisis Materi Fisika Peserta Didik SMAN 1 Selong Tahun Pelajaran 2016/2017. Jurnal Pendidikan Fisika dan Teknologi, 3(2). 